\title{
BAD PUBLIC LEADERSHIP IN SOUTH AFRICA: THE JACKIE SELEBI CASE
}

\author{
Erwin Schwella \\ School of Public Leadership, Stellenbosch University
}

\begin{abstract}
This article scrutinises the literature on bad public leadership and then presents an analysis of a South African case of bad public leadership. Leadership is analysed in terms of contextual as well as conceptual perspectives. The article emphasises that both context as well as conceptual and theoretical factors should be considered when analysing the emergence, manifestation and maintenance of bad public leadership. In this sense, the article speaks to both precipitating as well as predisposing issues as factors in causing and sustaining bad public leadership. The literature is then applied to the rise and the subsequent demise of Jackie Selebi, erstwhile National Commissioner of the South African Police Service and President of Interpol, as a case study of bad public leadership.
\end{abstract}

\section{Introduction}

South Africans are continuously subjected to allegations of bad leadership in the public sector. These allegations and, in some cases, resultant legal action, permeate all three spheres of South African governance. There is therefore a need to investigate bad public leadership by analysing the relevant and objectionable actions, understanding the related processes and identifying some personality factors found in bad public leadership. In this analysis, contextual as well as conceptual factors are reflected upon and then compared to knowledge gained through a case study within the South African public sector.

The case of Jackie Selebi, former National Commissioner of the South African Police Service (SAPS) and also former President of Interpol, was selected. Selebi, who was appointed National Commissioner of the SAPS in January 2000, was the first National Commissioner in the

Scientia Militaria, South African Journal of Military Studies, Vol 41, Nr 1, 2013, pp. 65-90. doi: $10.5787 / 41-1-1053$ post-1994 South African history to be appointed in this position from a non-policing background. $\mathrm{He}$ also was a leading figure in politics, and specifically in the African National Congress (ANC). During the struggle 
years and the years following the democratic elections of 1994, Selebi was deployed by the ANC in important posts. Much was expected of him, specifically given the well-documented destructive role of police practices in South Africa under the apartheid regime and concerns created by the rising levels of crime in the country. As head of the SAPS, he led the biggest public service department in the country, both in terms of human capital as well as in budget. Ethical and effective expectations, typically associated with policing in general and specifically with policing in a constitutional democracy under the rule of law, were held of him. However, it seems he dismally failed these highly held expectations, leading to questions on what had happened, how this had happened and what could be learnt from the Selebi case.

\section{Leadership: Some Contextual Considerations}

The primary focus in this article is on South African leadership, and the more specific perspectives are on South African public leadership. In order to contextualise the focus and perspectives further it is necessary to deal with the African, South African and sector contexts of leadership. Rotberg contrasts good and bad leaders in the African context, as follows:

Good leaders globally, not only in sub-Saharan Africa, guide governments of nation-states to perform effectively for their citizens. They deliver high security for the state and the person; a functioning rule of law; education; health; and a framework conducive to economic growth. They ensure effective arteries of commerce and enshrine personal and human freedoms. They empower civil society and protect the environmental commons. Crucially, good leaders also provide their citizens with a sense of belonging to a national enterprise of which everyone can be proud. They knit rather than unravel their nations and seek to be remembered for how they have bettered the real lives of the ruled rather than the fortunes of the few. ${ }^{1}$

In contrast to these exemplary leaders, less benevolent - even malevolent leaders, deliver far less by way of performance, according to Rotberg. Under such leaders' stewardship, roads fall into disrepair, currencies depreciate, real prices inflate, health services weaken, life expectancies slump, people go hungry, schooling standards fall, civil society becomes more beleaguered, the quest for personal and national prosperity slows, crime rates accelerate, and overall security becomes more tenuous. Rotberg also refers to the ethical dimensions of bad leadership stating that under bad leadership, corruption grows. Funds flow out of 
badly led countries into hidden bank accounts, discrimination against minorities (and occasionally majorities) becomes prevalent and civil wars begin. ${ }^{2}$

In his address to the people of Africa held in Accra, Ghana in 2009, US President Barack Obama provided insights on the importance of democratic institutions for good African leadership. He stated that strong and sustainable democratic governments must be supported. Each nation gives life to democracy in its own way, and in line with its own traditions. History, however, offers a clear verdict that governments that respect the will of their own people are more prosperous, more stable and more successful than governments that do not. This is not only about holding elections; it is also about what happens between elections. According to Obama, repression takes many forms, and too many nations are plagued by problems that condemn their people to poverty. It has to be noted that no country is going to create wealth if its leaders exploit the economy to enrich themselves and that no person wants to live in a society where the rule of law gives way to the rule of brutality and bribery. This is tyranny and not democracy, and has to end.

Obama further stated that in the 21 st century, capable, reliable and transparent institutions are the key to success. This requires strong parliaments and honest police forces, independent judges and journalists, and a vibrant private sector and civil society as the things that give life to democracy, and that which matters in peoples' lives. ${ }^{3}$ In order to introduce a South African perspective in this regard, it is apt to quote Mandela, who stated what the relationships between good governance, rule of law and leadership should be:

In its proper meaning equality before the law means the right to participate in the making of the laws by which one is governed, a constitution which guarantees democratic rights to all sections of the population, the right to approach the court for protection or relief in the case of the violation of rights guaranteed in the constitution, and the right to take part in the administration of justice as judges, magistrates, attorneys-general, law advisers and similar positions. In the absence of these safeguards the phrase "equality before the law", in so far as it is intended to apply to us, is meaningless and misleading. 4

From this statement by Mandela, it can be deduced that good public leadership respects the values of democracy, the rule of law and good governance. In contrast to this, in the reasoning of Mandela, bad public leadership disregards these values at the expense of the population. The role and impact of sector context is a 
significant recurring theme identified in respect of leadership. Specifically the question is whether the public sector context requires more specific and different behaviours on the part of public leadership than in the case of private leadership. Put more theoretically, the question is whether context, and in this case the public context, matters and if so, what the impact of this public context would and should be.

In the literature, such as the Harvard Conversations on Leadership, ${ }^{5}$ there seems to be agreement that leadership is highly contextual. The challenge is to determine how to abstract a set of leadership concepts that apply across contexts without sacrificing an understanding of how the conditions and qualities involved in leadership vary across contexts. Frederickson is clear on leadership in a public sector context, where he states:

The ordinary view of leadership has a generic, disembodied quality to it - as if to suggest that great leaders are able to lead effectively in any setting. Although most of us know this to be nonsense, it is nevertheless the formulaic description of leadership. Badarocco calls such a view of leadership what it is - nonsense - and argues correctly that there can be no great leadership ... without a deep substantive knowledge of the technological and bureaucratic characteristics of the specific setting in which leadership is expected. Context matters and the governmental context matters greatly, as any public administrator knows. ${ }^{6}$

The view here is that public leaders function in very different contexts from their counterparts in the private domain. Pollitt refers to the work of Ranson and Stewart and Rainey respectively in which the essential differences and distinctive qualities of the public context are elaborated upon. ${ }^{7}$ These include, amongst others:

- Public leadership takes place within the social political system creating the need to understand and work with political processes and role players. The status and motivation of political role players are not the same as those of board members of any company;

- $\quad$ Public leaders have to work with public pressure and protest. In the public domain, these matters are necessary for functional democratic purposes and are not signs of something that might have gone wrong as they may be interpreted in the private sector context; and 
- Public leaders should actively pursue a sense of democratic public accountability where openness is not only tolerated or accepted, but actively encouraged.

All of these factors seem to indicate that public leaders function in very different contexts from their counterparts in the private domain. For the purposes of this article, the base assumption will therefore be that public and private leadership are significantly different, if not in process then in context and expectations of the relevance of outcomes.

\section{Understanding Public Leadership: Conceptual Perspectives}

Leadership has been extensively studied for centuries. It is possible to classify leadership studies roughly into five broad leadership approaches in order to understand and explain leadership. Detail in respect of these approaches can be found in DuBrin and Schwella. ${ }^{8}$

The traits approach (also referred to as characteristics of leadership approach) asserts that leaders are born with particular traits, which were initially linked to physical traits such as attractiveness and/or personality traits such as intelligence. The most current attempt to find, prescribe or cultivate such characteristics relates to the quest for emotional intelligence (EQ). ${ }^{9}$ The behavioural approach to leadership states that leaders should think and act in ways that ensure that the team who does the work functions well as a team while simultaneously focusing on getting the job done. Nurturing the team is referred to as relationshiprelated behaviour, while getting the work done is referred to as task-related behaviour. The leadership prescription here is that neither relationship-related nor task-related behaviour should be neglected in successful leadership. The situational or contingency approach to leadership departs from the behavioural approach to leadership, but then argues that it is not necessary to focus on relations and tasks under all circumstances or at all times. The leadership prescription is that, depending on situational variables such as the nature of the task, leader-member relationships and the amount of position power the leader possesses, the leader may focus on either task or relationships rather than on both all of the time. The transformational or new charismatic approach to leadership requires of leaders to concern themselves continuously with a process in which organisational destiny, products and work are dealt with by means of creating and sharing a powerful vision for and of the organisation. The vision is realised through inspiring the total organisation to strive towards the vision. Planning and implementation of these plans are also needed to realise the vision concretely. Teaming creates and maintains strong teams to pursue the organisational vision. Finally, recycling relates to incorporating information and 
knowledge after evaluation of organisational effort to ensure that continuous performance improvement takes place through processes of change, adaptation and re-envisioning. The social learning approach to leadership is linked to the recycling step in the transformational approach and requires that organisations continuously learn and experiment in order to improve capacity and performance. Leaders should therefore not be directive and authoritarian, but should rather be facilitators creating space for experimentation and learning. The assumption here is that some of the problems which organisations face are so complex that there are no easy or ready answers for them. Leaders should therefore facilitate systems, group, team and individual learning to develop new competencies that the organisation and its members do not possess initially. Harvard leadership trainer Ronald Heifetz describes this type of leadership as leadership without authority in situations where there are no easy answers. The leadership prescription here requires that leaders create the space for and encourage learning to take place in the organisation by being facilitative rather than directive. ${ }^{10}$

Finally, for the purposes of this article, public leadership as a context-related leadership approach is defined by the author as follows: democratic and effective public leadership is action taken through a dynamic and transparent process involving the leader with relevant others in the inclusive setting and effective realisation of legitimate, legal and socially valuable goals and objectives. The process requires continuous democratic and organisational learning to progressively enhance effective and proper policy making and service delivery aimed at improving citizens' quality of life. Having dealt with some contextual and conceptual aspects of leadership and public leadership, attention can now be focused on bad public leadership.

\section{Bad Public Leadership: A Literature-Based Analysis}

Schyns and Hansbrough confirm that the leadership research landscape has shown a shift in the recent past. Rather than a mere focus on leadership in its positive and constructive manifestations, a focus on the darker side of leadership has emerged. This perspective accepts that leaders can and also do cause harm. This emerging focus opens up the possibilities of broadening the scope and nature of leadership inquiry in order to gain leadership understanding as well from this perspective. ${ }^{11}$

In order to construct a theoretical framework for the analysis of cases of bad public leadership it is useful to focus on the theoretical elements of leaders, followers and situational factors and the emerging interactions of these factors. According to Kellerman, bad leadership can be divided into two categories, namely 
ineffective and unethical leadership. ${ }^{12}$ Ineffective leadership simply fails to produce the desired change and results and therefore falls short of its intention. Leaders are generally judged as ineffective as a result of the means that they employ or fail to employ rather than the ends that they pursue. Such leaders just do not have the capacity to reach the set goals. Unethical leadership is leadership that fails to distinguish between right and wrong. Good ethical leaders are contrasted to unethical leaders on the following bases:

- Ethical leaders put the needs of their followers above their own needs; unethical leaders do not;

- $\quad$ Ethical leaders exemplify private virtues such as courage and temperance; unethical leaders do not; and

- Ethical leaders lead in the interest of the public good; unethical leaders do not.

Good leadership is constituted by effective and ethical leadership whereas bad leadership relates to ineffective and unethical leadership. Based on these basic points of departure, Kellerman distinguishes seven types of bad leadership. ${ }^{13}$ Incompetent leadership is found where the leader and at least some followers lack the will or skills, or both, to sustain effective action with regard to leadership challenges. Such leaders do not create positive change. Rigid leadership represents leadership where the leader and at least some followers are rigid, unyielding and uncompromising to accommodate reality. Although they may be competent they are unable or unwilling to adapt to new ideas, new information or changing times. Intemperate leadership relates to leadership where the leader lacks self-control. In this deficiency, the leader is aided and abetted by followers who are unwilling or unable to intervene effectively in order to curb the intemperate actions of the leader. Callous leadership occurs where the leader and at least some followers are uncaring or unkind, ignoring or discounting the needs, wants and wishes of the majority of group members or the organisation. This often applies especially to less powerful members of the community or group. Corrupt leadership manifests where the leader and at least some followers lie, cheat and steal. Self-interest is put above public interest. As all people seem to put self-interest to some extent first, the careful formulation of putting self-interest first "to a degree that exceeds the norm" is a necessary qualification here. Insular leadership is characterised by a situation where the leader and at least some followers minimise or disregard the health and welfare of the people outside of the group who are supposed to benefit from the actions of the group or organisation for which they are directly responsible. Insular leadership is leadership so focused on those within the group or organisation that it ignores the 
common good or the general welfare of those for whom they can or should accept responsibility. Evil leadership is more common than expected, even when defined as situations in which the leader and at least some followers commit atrocities. Again, followers play a key role here. These followers condone and/or use pain ordered by and committed with the leader as an instrument of power in order to do harm to people. Across the world, there is evidence of evil public leadership being at work.

Lipman-Blumen provides a list of personal qualities of bad leaders. She refers to these bad leaders as "toxic leaders". These qualities include a lack of integrity where leaders are cynical, corrupt or untrustworthy. Toxic leaders demonstrate insatiable ambition, prompting such leaders to put their own sustained power, glory and fortunes above the well-being of their followers. Their enormous egos blind them from the shortcomings of their own character and thus limit their capacity for self-renewal. Toxic leaders project arrogance preventing them from acknowledging their mistakes and, instead, leading them to blame others for their failure. The amorality of these leaders makes it nearly impossible for toxic leaders to discern right from wrong. A prevalent avarice drives toxic leaders to pursue money and what money can buy as their highest priority. ${ }^{14}$

These qualities of toxic leaders manifest in bad leadership behaviours. According to Lipman-Blumen, such behaviour includes that toxic leaders leave their followers (and sometimes non-followers) worse off than they found them by deliberately undermining, demeaning, seducing, marginalising, intimidating, demoralising, disenfranchising, incapacitating, imprisoning, torturing, terrorising or even killing them. They engage in corrupt, criminal and/or other unethical activities while deliberately feeding their followers illusions that enhance the leader's power and impair the followers' capacity to act independently. Their actions include depicting themselves as the only actors who can "save" the followers. Toxic leaders also subvert those structures and processes of the system intended to generate truth, justice and excellence and the systems discouraging engaging in criminal acts. They build totalitarian or narrowly dynastic regimes, which undermine the legal processes for selecting and supporting new leaders. These leaders fail to nurture other leaders, including their own successors (with the occasional exception of blood kin) or otherwise improperly engage in clinging to power. Toxic leaders may initially treat their own followers well, but often persuade them to hate and/or destroy others. They identify alleged scapegoats and incite others to castigate them. Toxic leaders fail to recognise or ignore and/or promote incompetence, cronyism and corruption. They fail both to understand the nature of relevant problems and to act competently and effectively in situations requiring leadership. ${ }^{15}$ 
An interesting set of process questions relate to how salient dimensions of leaders, followers and organisations interact within organisations to enable and sustain unethical and destructive leadership behaviours. Chandler and Fields provide a useful process perspective of what they term "unethical and destructive leadership". The three related questions in this discussion are:

1. How and why did these leaders venture down these paths of bad leadership?

2. Why did these leaders persist in these behaviours, which are well known to be unethical and destructive?

3. Why were these behaviours tolerated or, in some instances, even rewarded by organisations and/or followers? ${ }^{16}$

In respect of the first question, Chandler and Fields argue that leaders degenerate down the path of bad leadership to destructive bad leadership behaviours due to deficiencies in leadership selection processes letting narcissistic leaders lacking moral development and a responsibility disposition through as leaders. These deficiencies in the selection of leaders are compounded if organisational environments exhibit weak ethical commitment as well as minimal ethical reasoning. When goal setting (and probably also goal realisation) pressures build up, there is a trend to act to reach the goals at the expense of ethical behaviour. Intense competition and unstable and unpredictable organisational environments lead to pressures on resources and time, providing conditions conducive to unethical behaviours.

Dealing with the second question on why the leaders persist in these negative actions, Chandler and Fields argue that leaders persist with unethical and bad leadership behaviours as part of the processes of leading, managing and decision-making in the organisation. ${ }^{17}$ The leadership and management processes relate to leader characteristics where leaders pursue self-enhancement motives overriding all other personal, professional and ethical values. This emphasis on leadership self-enhancement overrides all other values and fosters unethical and destructive leadership behaviour. In some cases, leaders realise that the results of their actions are bad, but they nevertheless increase their actions with escalated commitment. This shows a disregard for the real situation, counters negative feedback and sustains unethical and destructive leadership. Chandler and Fields state that such decision-making by leaders who persist with bad leadership behaviour, is influenced by self-deception. Such self-deception leads leaders to deny or conceal the truth, avoid personal commitment, evade the realities through deliberate ignorance, emotional detachment, self-pretence and rationalisation. Through 
selective perception, moral implications of decisions are pushed into the background.

Chandler and Fields further argue that leaders persist in unethical and destructive bad leadership behaviour as a result of organisational dimensions related to ethical climate and norms, environmental uncertainty and reactions to perceived threats or threat rigidity. ${ }^{18}$ The ethical climate is influenced by organisational history, culture and the values and actions of leaders as well as ethical policies, legal oversight and accountability. Even if there are formal codes of ethics or other mechanisms in place, bad leaders may ignore these and their example may lead to widely held perceptions that the codes and policies are merely symbolic rather than really normative, corroding ethical standards. When contextual environmental conditions are stable and predictable, ethical standards are generally more prevalent and followed than when there are instability and uncertainty about ethical standards. Expectations and a demonstrated reality of being called to account for actions also improve leadership and ethical behaviours.

Environmental instability and uncertainty may lead to a tendency to cut corners. Threat rigidity refers to a negative or adverse situation over which decisionmakers have little control and where there is a perceived potential of substantive loss that may occur for the organisation under threat. Leaders then react with reducing uncertainty by exercising caution, restricting information and centralising control and power with the leaders. Excessive emphasis on control and leadership power can lead to a reduction in the organisational processes that put limitations on bad leadership behaviour.

In respect of the third question on why unethical and/or destructive behaviours are tolerated or, in some instances, even rewarded by organisations and/or followers, Chandler and Fields relate to the characteristics of followers and aspects of organisational dynamics. ${ }^{19}$

In respect of follower characteristics, the self-concept of followers can be manipulated into being conformers and colluders in the bad leadership of leaders. Followers who get manoeuvred into expectations of unchallenging requests for obedience will probably accede to bad leadership. Followers who perceive their freedom and power to act as high, possess self-efficacy and will more likely resist bad leadership than those followers who are submissive and suppressed. Too much value alignment or forced acceptance of value alignment may inhibit follower resistance to bad leadership. Followers may engage in modelling the roles of leaders. If the role model is unethical then the followers following the model will not resist bad leadership. An interesting aspect related to the characteristics of followers is the 
organisational commitment of followers involving affective attachment to and identification with the organisation. High levels of organisational commitment may result in followers denying or ignoring bad leadership behaviour from leaders. Organisational commitment to positive organisational dimensions, such as ethics and morality, may also increase follower intolerance of bad leadership.

Chandler and Fields argue that organisational dynamics impact on the tolerance of bad leadership through to the evaluation of actions, the dynamics of the feedback environment and conformity pressures. ${ }^{20}$ The feedback environment provides stakeholders with continuous feedback on their behaviour. Feedback about particular behaviour sets can be negative or positive. If feedback reinforces bad leadership behaviour, it could lead to an increase in such behaviour. Contexts that increase conformity pressures from unethical destructive leaders create conditions where group pressure results in the acceptance and condoning of bad leadership behaviour. Research evidence suggests that certain conformity pressures from especially authoritative figures, such as leaders, may result in ordinary people conforming to and condoning bad leadership behaviours.

A recurring theme in explaining bad leadership relates to narcissism. ${ }^{21} \mathrm{Higgs}$ refers to empirical research identifying four distinct aspects of narcissism. ${ }^{22}$ These are:

- Exploitativeness/entitlement which is described as: "I demand the respect due to me";

- Leadership/authority: "I like to be the centre of attention";

- Superiority/arrogance: "I am better than others"; and

- Self-absorption/self-admiration: "I am pre-occupied with how extraordinary I am".

After a comprehensive review of the literature, Higgs identifies a number of behaviours associated with narcissistic personalities, including grandiosity of personal belief systems, self-absorption and a sense of entitlement. Narcissistic personalities thus illustrate a fragile self-esteem, hostility to negative feedback and an inflated self-view. Narcissistic personalities have an inordinate need for positive reinforcement and admiration and they seek attention continuously. They show dysfunctional needs for power, achievement and dominance and are intolerant of criticism. They are unwilling to compromise, lack empathy and are inflexible. Narcissism is not only associated with negative leadership outcomes as, according to Higgs, there is also evidence of the positive effects of narcissism for 
transformational leadership where strong visions have to be created and shared and where inspiration and assertiveness are required. It is therefore necessary to distinguish between the possible positive and negative aspects of narcissism. ${ }^{23}$

The negative aspects of narcissism suggest a range of negative consequences, including the creation of blame and a toxic culture, where successes are claimed by the leader and failures are blamed on others. There are indications of abuse of power for personal aggrandisement, unethical behaviour and, often, organisational damage and/or collapse.

McFarlin and Sweeney investigated a breadth of research on the impact of narcissism on effective and ethical leadership. On the effectiveness of narcissistic leaders in respect of performance, they conclude,

In summary, the relation between narcissism and performance in the literature is a lot like narcissists themselves - there is a lot of bluster, some promise, and unreliable success, with only a high self-opinion surviving. The majority of research shows no positive relation between performance and level of narcissism. ... narcissists are not better performers; indeed, on some occasions the research shows they are poor performers. ${ }^{24}$

In respect of narcissism and ethical issues of leadership, McFarlin and Sweeny state that the research supports conclusions in a comparative study that narcissism predicts a high probable potential for criminal behaviour. Overall, the conclusion is that narcissism is closely related to poor attitudes and behaviour concerning ethical practices. This suggests that, under positive conditions and favourable circumstances, narcissists may be effective leaders, but there is a probability that they may have challenges in respect of ethical leadership. ${ }^{25}$

Having discussed the impacts of narcissism on leadership performance and coming to the conclusion that these leaders may be tempted towards unethical and ineffective leadership under favourable conditions, the focus now moves to the process of leadership corruption. According to Wesche, May, Peus and Frey, the process of turning corrupt is based upon a cost-benefit analysis by potential perpetrators. Costs and benefits are calculated in terms of material costs and benefits, social costs and benefits and psychological costs and benefits. ${ }^{26}$

Material costs include a calculation of the cost of legal prosecution, punishment and the costs of losing employment, while material benefits may include financial gain and career progress. Social costs include possibilities of ostracism and the destruction of personal and professional reputations and relationships. Social 
benefits are related to respect and admiration following from erroneous perceptions of followers, namely that financial and leadership successes are based on proficiency rather than on the benefits of corruption. Psychological costs include feelings of guilt, shame, fear and stress. Psychological benefits may include feelings of power, status, success and even invulnerability.

The assessment of the costs and benefits is calculated against the background of opportunities created by organisational structure and control mechanisms where structures, with power centralised in the hands of the few coupled to organisational complexity, increase the potential for corrupt action. On the other hand, proper legislation and regulation may help to control choice in respect of engaging in corrupt behaviour. Control - or the lack thereof - influences the expected material and social cost-benefit calculation, which depends on the probability and cost of detection. Personal individual attitudes will influence the impact of the cost-benefit analysis. Honest and humble leaders will probably not engage in activities that could violate their important and strongly held values. On the other hand, leaders who are Machiavellian, low on idealism or who follows utilitarian ethics, could be inclined to engage with corrupt acts.

Based on this literature review on the analysis of bad public leadership, it is now possible to infer a set of analytical categories within which individual cases of bad public leadership can be analysed.

\section{Analytical Categories for Individual Leadership Case Analysis}

The case analyses of different individual cases of bad public leadership can be systematised in terms of the following analytical categories based upon the literature review presented above in terms of:

- Classifying the leadership actions in terms of:

$\circ$ being unethical and/or ineffective;

○ type of bad public leadership; and

- the qualities of the bad public leader in the case.

- The processes involved in analysing and understanding the bad public leadership actions related to the processes involved in:

○ the process of the corruption of the leader to become a bad public leader;

○ the process related to how and why bad public leadership occurred; 
○ the process explaining why the bad public leadership manifestations persisted; and

- organisational processes which resulted in the bad public leadership being tolerated or even rewarded.

- The personality aspects related to the bad public leadership in terms of:

- narcissistic elements of the behaviour;

○ attitudes of the leaders; and

$\circ$ behaviours of the leaders.

In the following sections, examples of a bad public leadership cases in the South African context will be analysed using the analytical framework developed from the literature presented here.

\section{Bad Public Leadership, a South African Case Study: Jackie Selebi}

South Africa is renowned for the good public leadership displayed so evidently by leaders such as Nelson Mandela, Desmond Tutu and FW de Klerk. However, recently South Africa has also delivered examples of bad public leadership. When observing the manifestations of corruption, many examples of bad South African public leadership can be found in the media, in court cases and in other public forums. Examples that can be listed are those of Hansie Cronje, the South African cricket captain, who admitted to having taken bribes to fix matches; Carl Niehaus, a previous South African ambassador and senior official and member of the ANC party cadre, who admitted to many examples of transgressions of ethical expectations and breaches of trust; and Jackie Selebi, an ex-National Commissioner of the South African Police Service and President of Interpol, who was found guilty on serious charges of corruption in South African courts and sentenced to a long term of imprisonment for these crimes. Given the nature and scope of the positions held by Selebi and the seriousness of his crimes, the case analysis done here will focus on him.

Jackie Selebi: A brief biography

Jacob (Jackie) Sello Selebi was born on 7 March 1950 in Johannesburg and is the former National Commissioner of the South African Police Service (SAPS) and a former President of Interpol.

Basson documents that Selebi was trained as a teacher. As a young teacher, he taught at Musi High School in Pimville, Soweto. One of his former learners 
described Selebi as a lover of Mafia novels. The learner also noted that Selebi "... always had an eye for a quick buck". ${ }^{27}$ According to this source, when Selebi was a student and worked in a bookstore in Johannesburg, he would cut deals by selling books and stationery to learners outside the store in a dark passage at discount prices. According to his former learners referred to by Basson, as a teacher, Selebi was regarded as tough. He shadow-boxed often and was fast on his feet and good with his fists. As somewhat of a maverick, he was loved by the learners, but most of the other teachers did not like him as he was thought to be a bad influence on the impressionable minds of young learners. He allowed learners to smoke in class, and on occasion, returned two days late with a school group whom he had accompanied on a school trip. When there was an attempt to discipline him for this, the learners walked out of the classroom in protest. Selebi also seldom joined the other teachers in the staff room and preferred "hanging around" with the learners. During these years, Selebi was also described as arrogant, abrasive, tactless and rude. During his last years as a teacher, Selebi became heavily involved in politics and increasingly clashed with the police. After being held in prison under the then Terrorism Act for 10 months, Selebi went into exile in Tanzania in 1979.

While serving the ANC in exile and after returning to South Africa from

exile after democratisation, Selebi filled the following important positions and offices:

- Representative of the Soviet Union's World Federation of Democratic Youth in Budapest, Hungary, from 1983 to 1987;

- Head of the African National Congress (ANC) Youth League in 1987 while in exile in Zambia;

- $\quad$ Member of the National Executive Committee of the ANC also in 1987;

- Official responsible for the repatriation of ANC exiles back into South Africa in 1991;

- $\quad$ Head of the Department of Welfare of the ANC in 1993;

- $\quad$ Elected Member of Parliament for the ANC in 1994;

- South African ambassador and permanent representative to the United Nations from 1995 to 1998 ; and

- $\quad$ Director-General of the Ministry of Foreign Affairs from 1998 to 1999.

When Selebi was appointed National Commissioner of the SAPS in 2000, the organisation was in a process of serious and deep transformation. According to 
Basson, ${ }^{28}$ this transformation of the South African Police Service after 1994 created numerous complex challenges. During 1997, President Mandela went so far as to appoint the chairman of the South African Breweries, Meyer Kahn, to the police as turnaround specialist. Kahn left the SAPS at the end of 1999, admitting to have achieved less than expected. Selebi was appointed special advisor to the soon-toretire first National Commissioner of the SAPS, George Fivaz, and as National Commissioner elect. Fivaz retired on 31 December 1999 and was succeeded by Selebi on 1 January 2000. Selebi was now the head of the single national police service provided for in the South African Constitution, 1996.

Selebi drew controversy soon. He started out by refusing to wear a uniform consistently and argued that he was a manager rather than a policeman. He was also criminally charged by two separate police officers soon after his appointment. In the first case, he allegedly called Sergeant Jeanette Mothiba, “... a f.....g gorilla" during an unannounced visit to the Brooklyn police station. Apparently, he was upset at not being treated with sufficient reverence and respect. In a subsequent investigation, he was found to have called her a "chimpanzee", which according to the official findings was less problematic as a chimpanzee is an "intelligent, small black monkey ..." He was not disciplined further after the incident and investigation.

Shortly before assuming duty as National Commissioner, Selebi also summoned Sergeant Julian Mabelane from the Letlhabile police station to his office in Pretoria. Mabelane alleges that Selebi threatened him that he would lose his job if he did not apologise to Selebi's uncle over a dispute over fodder between Mabelane and this uncle that dated back five years. According to Mabelane, Selebi called him into his office and said that he had waited for an opportunity to settle a score with him. After an investigation, the Independent Complaints Directorate (ICD) found that there was prima facie evidence that Selebi led Mabelane to fear for the security of his livelihood. Selebi was however not prosecuted for this after the Director of Public Prosecutions (DPP) had found there was no corroborating evidence for prosecution.

According to Haffajee, the appointment of Selebi was widely welcomed at the time of the appointment, as there was a belief that the political activist would make a good crime fighter. ${ }^{29}$ However, Haffajee further feels that the arrogance displayed in the chimpanzee incident contained the seeds of Selebi's destruction. She says, "Selebi believed himself to be infallible, but the easy way in which he was lured by lucre speaks instead of a man who has not mastered the ways of the world even though he was a globe trotter." Haffajee is also convinced that convicted drug dealer Glenn Agliotti courted Selebi and found Selebi's Achilles heel to be a love of 
the high life. In fact, she states that the court case was a narrative of a love and craving for the high life. This kind of life was not affordable on Selebi's official salary. The acceptance of the gifts from Agliotti was justified by Selebi as gifts from a man who was his friend. Selebi traded his reputation and the trust a nation put in him for a few pieces of silver and became the attendant for Agliotti, a drug dealer involved in organised crime. ${ }^{30}$

Selebi's illustrious career ending up as National Commissioner of the SAPS and first African President of Interpol, and his demise and fall is a case study of bad public leadership and the resulting effects. This is perhaps best illustrated in the judgement of Judge Meyer Joffe, in the matter of the State vs. Jackie Selebi. ${ }^{31}$ Judge Joffe, on finding the accused guilty on a charge of corruption, and sentencing him to a period of 15 years in prison stated, inter alia:

Mr Selebi, from 2000 until 2008 you occupied the position of National Commissioner of the South African Police Service. You led the service that is constitutionally enjoined to secure and preserve law and order in our country, to fight crime in all its forms and to protect all who find themselves within the borders of our country. This is indeed a high and illustrious office. Those under your command looked up to you with respect. They looked to you for guidance and direction. The citizens of this country likewise looked up to you in your exalted office. They sought leadership from you in the fight against the scourge of crime, which the people of South Africa were experiencing. It is in this context and the esteem in which the office that you occupied is held that reference must be made to your performance in the witness box during the trial....

Mr Selebi you were an embarrassment in the witness box.

Firstly, you were an embarrassment to the office you occupied. It is inconceivable that the person who occupied the office of National Commissioner of Police could have been such a stranger to the truth. Secondly, you must have been an embarrassment to those who appointed you. There can be no doubt that had they known the extent that you were prepared to depart from the truth when you thought it was necessary to do so, they would not have appointed you to that office. Thirdly, you must have been an embarrassment to the members of the South African Police Service who you led. It is not possible to measure the level of embarrassment of police men and women who are in the front line of the fight against crime, who daily 
put their lives on the line for their fellow citizens and whose credibility and truthfulness is relied upon by their fellow countrymen, when confronted by the reality that their former National Commissioner jettisons the truth when he thinks it will advance his case. ... Fourthly, you must have been an embarrassment to all right thinking citizens of this country. They are entitled to expect so much more from the National Commissioner of Police. For a citizen of this country it is incomprehensible that the National Commissioner of Police would be found to be an unreliable witness. Whilst there may be debate and difference of opinion as to competence, effectiveness, suitability and ability, it cannot be doubted that all the people of South Africa would join in rejecting a National Commissioner of Police who is found to be an untruthful witness. Fifthly and finally, Mr Selebi, you were an embarrassment to this court. It is beyond understanding that a person who occupied the high offices that you did, including that of National Commissioner of Police in which you must have come into contact with the courts, could have believed that any court would have accepted your mendacious and in some respects manufactured evidence.

This turn of events would have been difficult to predict at the time of $\mathrm{Mr}$ Selebi's appointment, which was generally hailed as a good appointment. An example is found in the editorial of City Press where the appointment was described and praised in the following way: "Hearty congratulations to Jackie Selebi on his appointment as the new Commissioner of Police after a short-lived but sterling job as the director-general of foreign affairs." "Knowing Selebi as we do," it continued, "... we believe he will acquit himself well in his new position.", 32

For City Press, Selebi's political connections were recommendations for the position. At the time, this newspaper noted that Selebi was

... no stranger to politics, having played a leading role in the South African Students Organisation, been head of the ANC Youth League, an executive member of the ANC and an MP. That is why we find it surprising that some white politicians claim to know little of him and others protest his lack of experience as a policeman. It is about time this position was given to a black person, with or without police experience. ${ }^{33}$ 
Other South African newspapers from across the political spectrum also confirmed these positive sentiments about the Selebi appointment at the time.

It is also clear from reports and the court record that Selebi was regarded highly by at least some of his closest SA Police Service colleagues, although there were noted exceptions. During the court case against Selebi, the prosecutor asked one of the then deputy police commissioners, Dr Mala Singh, about the relationship of the SA Police top management with Selebi. She answered that there had been no reason to doubt the commissioner. She was then asked why the police blindly defended Selebi and did not investigate the allegations about the corrupt relationships with Agliotti. Singh said it was "... my honest belief at the time that there was no reason to doubt the commissioner [Selebi] ... The only thing I fell back on was the nature of the man I knew."

This nearly blind loyalty is also confirmed by a statement issued by Selebi's four deputies in May 2006 after the Mail \& Guardian had revealed Selebi's links with Glenn Agliotti. The statement by commissioners Hlela, Pruis, Singh and Williams, who were the top management of the police at the time, started in the following way:

Vote of confidence in the National Commissioner: ... Top management of the South African Police Service, represented by the four Deputy National Commissioners and the Divisional Commissioners at Head Office, would like to reaffirm their confidence in - and loyalty to - the National Commissioner, Jackie Selebi. $^{34}$

This statement and vote of confidence followed after allegations of an improper relationship between Selebi and Glenn Agliotti started to surface in 2006. As it later became clear, this confidence was seriously misplaced. As it turned out Selebi was trialled and sentenced to 15 years' imprisonment for corruption based on this relationship with Agliotti, which led him to accept money and gifts from Agliotti, disclose secret information to Agliotti and assist Agliotti in covering up his involvement in high-level crimes such as the Kebble murder.

It is also evident that Selebi was initially protected from the consequences of his actions by high-level political and executive intervention by the then president, Thabo Mbeki. Basson relates how the then national Director of Public Prosecutions, Vusi Pikoli, informed Mbeki about the fact that the (now disbanded) Scorpions had sufficient evidence to arrest Selebi on allegations of corruption in 2007..$^{35}$ 
However, this did not result in the arrest of Selebi, but instead led to the suspension of Pikoli from office by Mbeki in September 2007 allegedly for an irretrievable breakdown of trust between Pikoli and his political overseer, the then Minister of Justice, Brigitte Mbandla. It now seems evident that the real reason for Mbeki to suspend Pikoli was to protect Selebi from arrest. It can also be speculated that the tide for Selebi would not have turned, had it not been for the removal of Mbeki from the presidency after the Polokwane conference of the ANC and the ascendance of President Jacob Zuma to power.

As stated, there were some exceptions to this collegial blind loyalty and alleged political protection. Over the years, some reports also emerged of the notorious arrogance as well as demeaning and destructive behaviours of Selebi during his term of office.

Some of these reports were confirmed in an interview with retired assistant commissioner (the current rank of major general) Chris Botha, who as a senior officer worked closely with Selebi. In this interview, Botha related how Selebi often acted with arrogance and in demeaning ways towards senior colleagues in official settings such as management meetings, during official trips and in different work contexts. Botha describes Selebi's behaviour as seriously flawed, biased and in many cases as totally unprofessional. According to Botha, Selebi often intimidated and denigrated colleagues in order to make his point, get his way or to show off his self-serving and claimed superiority. This behaviour led to a number of senior colleagues resigning, taking early retirement or just fading into insignificance in a subservient way. ${ }^{36}$ The picture that Botha provided of Selebi was of an extremely arrogant, self-serving and callous individual with a nasty habit of abusing his power and authority to destroy or humiliate. He ruled with fear, injury and insult in order to get his way.

Jackie Selebi: A leadership analysis

For the purpose of the analysis and using the analytical categories for individual leadership case analysis derived from the literature and presented above, the leadership of Jackie Selebi can be classified as ineffective and unethical.

Although there is evidence that he initially seemed to act effectively in the SAPS as a leader in designing and implementing strategies to deal with the crime challenges, over time he however turned out to be unethical and corrupt. In the long run, his unethical and corrupt actions inevitably also had a negative influence on his effectiveness. 
During the process of his downward spiral, albeit from a low base, into a bad unethical and corrupt public leader, he demonstrated many of the qualities of bad public leadership referred to in the literature. There is evidence that, during his term of office, he often showed a lack of integrity and behaved in cynical, corrupt and untrustworthy ways related to his role as leader as well as in respect of the corrupt behaviour for which he was eventually criminally punished. There is also evidence of arrogance and an ego that blinded Selebi from the shortcomings of his character and that this limited his capacity for self-renewal and ethical behaviour.

In respect of the process of his corruption, there is evidence that there were deficiencies in the leadership selection process by means of which Selebi was appointed to the position of National Commissioner. Selebi was highly regarded by important political role players and politically influential decision-makers. However, he had no professional experience of police work and he also was not put through a rigorous and/or objective selection process before his appointment. In his case, the appointment was based on his political acceptability and political connections rather than on his professional experience and previous performance in a professional police setting. A properly structured and rigorous selection process would probably have uncovered evidence of his arrogance and challenges in his moral development. This was latent, surfaced soon after his appointment and persisted and worsened throughout his term of office. However, as political loyalty and proven subservience to party requirements were more important than professional competency for the appointment, these matters were not taken into account at all. The literature predicts that the deficiencies in the selection process of leaders can let narcissistic and morally lacking leaders slip through the selection process. This prediction is confirmed in the case of Selebi.

Deficiencies in the selection of leaders are compounded if organisational environments exhibit weak ethical commitment as well as minimal ethical reasoning. There seems to be some evidence of this situation in respect of the SAPS environment. It is a known fact that the SAPS suffers from some corruption. This is also illustrated by the corruption of Selebi at the highest level of the SAPS. Although there were alarmingly clear indications of the possible corruption of Selebi, the organisational responses at the political and high professional levels of the SAPS were not indicative of ethical commitment and reasoning. The presented case refers to the interference of then President Mbeki when there was a possible warrant of arrest considered to call Selebi to account.

The trend in this regard is also confirmed by the defensive behaviour of Selebi's deputies in court and in issuing a declaration in which they confirmed their 
blind loyalty to the leader irrespective of being senior police professionals. Given these deficient and obviously wrong interventions on behalf of an arrogant and unethical leader and the results of this in the further deterioration of the behaviour of Selebi, the assumptions in literature about how weak ethical commitment and minimal ethical reasoning contribute to the occurrence and sustaining of bad leadership seem to be confirmed.

It is also evident that before and during Selebi's term of office, the SAPS was facing serious challenges in terms of transformation, the incidence of crime, organisational change and service delivery. In terms of the literature, this can be referred to as pressures in terms of goal setting and realisation, which can create a trend to emphasise goal attainment at the expense of ethical behaviour.

In the case of the SAPS, there is evidence that the transformation agenda as well as the crime fighting and service delivery challenges created pressures within which there is a demand from stakeholders for "strong" rather than ethical leadership. This emphasis probably contributed to the style of Selebi who was often seen as harsh, disciplinarian, autocratic and untactful in the quest for action and performance in respect of transformation and crime management. This "strong" leadership did however not relate to an emphasis on actions that are ethical in the case of the SAPS leadership, including the leader, Selebi. There therefore seems to be confirmation for the assumption in the literature that intense competition and unstable and unpredictable organisational environments lead to pressures on resources and time, providing conditions conducive to unethical leadership behaviour.

Unethical and/or destructive behaviours that are tolerated or, in some instances, even rewarded by organisations and/or followers, relate to the characteristics of followers and aspects of organisational dynamics. In this case, Selebi escaped the consequences of his behaviours from an early stage in his SAPS career when he was not properly disciplined for his behaviour in respect of calling a subordinate names and humiliating her when she did not treat him with the reverence he required. To Selebi, this was confirmation of how powerful his position in the SAPS had allowed him to become. The same reaction also occurred in the case of his attempt to take revenge against a SAPS colleague who previously prosecuted a Selebi family member. He once again escaped significant reprimand and/or corrective actions.

Selebi's followers also tolerated and even encouraged his behaviour as is evident from the way in which his deputies jumped to his defence and justification in their public statement of loyalty and in court during his trial. This supplies 
evidence, that, in terms of follower characteristics, the self-concept of followers was manipulated into that of conformers and colluders in bad leadership and acceded to in Selebi's bad leadership. The followers in the Selebi case did not resist Selebi's bad leadership and at best acted in a submissive and suppressed way. This was illustrated by the actions of his deputies in publicly declaring their loyalty to him when he was alleged to be corrupt and during his court case.

The SAPS shows signs of having a strong bureaucratic and especially a resilient police culture, which seems to transcend the transformational changes through which the SAPS is going. This probably also leads to too much value alignment, or forced acceptance of this value alignment, related to unquestioning loyalty and conformity inhibiting follower resistance to bad leadership. The levels of unethical and corrupt behaviour in the SAPS may indicate follower modelling, which may show that followers will not resist the model of bad leadership presented to them from the top. Under these conditions, loyalty rather than ethical behaviour is rewarded. The dominant culture in the SAPS currently and during Selebi's reign seems to confirm the impact of organisational dynamics on the tolerance of bad leadership through to the evaluation of actions, the dynamics of the feedback environment and conformity pressures. The feedback environment here seems to have reinforced bad leadership behaviour and an increase in such behaviour. In this case, the continuous and seemingly generally unsuccessful "transformation" of the SAPS increased conformity pressures from Selebi and other unethical destructive leaders and created conditions where group pressure resulted in the acceptance and condoning of bad leadership behaviour. Research evidence suggests that, given conformity pressures from especially authoritative figures such as leaders, this may result in ordinary people conforming to and condoning bad leadership behaviours. There is ample evidence in this case of these dynamics at work. It seems as if bad leadership was rewarded while attempts to curb bad leadership were suppressed in the culture prevailing in the SAPS.

Finally, one should probably be careful not to make unsubstantiated diagnoses on limited evidence about Selebi's personality as being narcissistic. However, from the observed and reported evidence from a number of sources, it seems Selebi clearly acted continuously throughout his career in the SAPS and also previously as a teacher, with a set of observable poor attitudes and behaviour concerning ethical practices. As is suggested by the theory, this may be related to narcissist tendencies where, under positive conditions and conducive circumstances, these behaviours and actions may result in effective leadership. There is, however also a probability that these leaders may experience challenges in respect of ethical leadership. 
In any analysis it seems to be clear that the leadership behaviours repeatedly illustrated by Selebi eventually led him to corruption and a jail sentence. The attitudes he displayed were based on intolerable levels of arrogance and cynicism employed for personal gain in an unethical way rather than for the public good. This is an example of bad leadership in action encouraged by systemic disfunctionality and it can be predicted that, if the system challenges are not addressed in a deliberate and professional way, more bad public leadership will occur in the SAPS.

\section{Conclusion}

The research on which this article is based, attempted to provide a systematic academic analysis of bad public leadership in a South African case study. Related to the literature, the results of the case study clearly points to the clear and distressing unacceptability of Selebi as a bad public leader. There is evidence of numerous bad practices in the systemic, institutional, professional and personal practices resulting in seeming impunity where a bad public leader was allowed for too long to live above the law while being the main proponent of the law.

This clearly and embarrassingly shows horrendous disrespect for the people whose safety and security were in the hands of a now proven bad public leader, Jackie Selebi. It also augments the role of ordinary South Africans to speak truth to power. Hopefully this can continue in a respectful way, supported by arguments based on evidence and research enhancing public accountability, rather than under conditions restrained by official secrecy and curbs on media and public debate.

The case of Jackie Selebi illustrates how public and media oversight finally brings accountability even under conditions of serious challenges.

\section{Endnotes}

${ }^{1}$ Rotberg, RI. "The roots of Africa's leadership deficit". Compass: A Journal of Leadership 1/1. 2000. 28.

2 Ibid., p. 29.

${ }^{3}$ Obama, B. "Obama commits to opening trade doors for Africa". YouTube. 13 July 2009. <http://www.youtube.com/watch?v=_IPinpTMW9A > Accessed on 15 May 2012.

${ }^{4}$ Mandela, N. No easy walk to freedom. New York: Penguin Classics, 2002.

${ }^{5}$ Harvard University School for Public Leadership. Harvard Conversations on Leadership. March 2003. 
<http://www.ksg.harvard.edu/leadership/recurring_themes_conversations.ht ml> Accessed on 15 February 2009.

${ }^{6}$ Frederickson, G. "Public administration and quiet leadership". PA Times Archives 26/6. 2003. 6.

${ }^{7}$ Pollit, C. The essential public manager. Buckingham: Open University Press, 2003.

${ }^{8}$ DuBrin, AJ. Principles of leadership ( $6^{\text {th }}$ ed.). Cincinnati, OH: South-Western Cengage Learning, 2010.

${ }^{9}$ Schwella, E. "Administrative reform as adaptive challenge: Selected public leadership implications". Politeia 27/2. 2008. 25-50.

${ }^{10}$ Heifetz, RA. Leadership without easy answers. Cambridge, MA: The Belknap Press of Harvard University, 1998.

${ }^{11}$ Schyns, B \& Hansbrough, T. When leadership goes wrong: Destructive leadership, mistakes and ethical failures. Charlotte, CT: Information Age Publishing, 2010.

${ }^{12}$ Kellerman, B. Bad leadership: What it is, how it happens, why it matters. Boston, MA: Harvard Business School Press, 2004.

${ }^{13}$ Ibid.

${ }^{14}$ Lipman-Blumen, J. Allure of toxic leaders: Why we follow destructive bosses and corrupt politicians - and how we can survive them. New York: Oxford University Press, 2004.

${ }^{15}$ Ibid.

${ }^{16}$ Chandler, DJ \& Fields, D. "Ignoring the signposts: A process perspective of unethical and destructive leadership". In Schyns \& Hansbrough op. cit., pp. 99-143.

${ }^{17}$ Ibid. pp. 111-114.

${ }^{18}$ Ibid. pp. 115-118.

${ }^{19}$ Ibid. p. 125.

${ }^{20}$ Ibid. pp. 126-129.

${ }^{21}$ McFarlin, DB \& Sweeney, PD. "The corporate reflecting pool: Antecedents and consequences of narcissism in executives". In Schyns \& Hansbrough op. cit., pp. 247-283.

${ }^{22}$ Higgs, M. "The good, the bad and the ugly: Leadership and narcissism". Journal of Change Management 9/2. 2009. 165-178.

23 Ibid.

${ }^{24}$ McFarlin \& Sweeney op. cit., p. 266.

${ }^{25}$ Ibid., p. 267. 
${ }^{26}$ Wesche, JS, May, D, Peus, C \& Frey, D. "Leadership corruption: Influence factors, process and prevention”. In Schyns \& Hansbrough op. cit., pp. 305353.

${ }^{27}$ Basson, A. Finish \& klaar: Selebi's fall from Interpol to the underworld. Cape Town: Tafelberg, 2010.

${ }^{28}$ Basson op cit., p. 17.

${ }^{29}$ Haffajee, F. "Foreword". In Basson op. cit., pp. iv-v.

${ }^{30}$ Ibid., p. v.

${ }^{31}$ Joffe, J. "S v Selebi (Judgement on Sentence) (25/2009) ZAGPJHC 58". SAFLII. 3 August 2010. < http://www.saflii.org/za/cases/ZAGPJHC/2010/58.pdf> Accessed on 17 May 2012.

${ }^{32}$ Ever-fasternews.com. "How the press welcomed Jackie Selebi's appointment". Politicsweb. 17 November 2006.

<http://www.politicsweb.co.za/politicsweb/view/politicsweb/en/page71619? oid=186747\&sn=Detail\&pid=71619> Accessed on 10 November 2012.

${ }^{33}$ Ibid.

${ }^{34}$ South African Police Service. "Vote of confidence in the National Commissioner: Top management of the South African Police Service Deputy National Commissioners Hlela, Pruis, Sing and Williams”. SAPS. 26 May 2006. <http://www.saps.gov.za/_dynamicModules/internetSite/newsBuild.asp?my URL=651> Accessed on 30 May 2012.

${ }^{35}$ Basson op. cit., p. 135.

${ }^{36}$ Botha, C. Personal interview. January 2012, Mossel Bay. 